\title{
Thionville
}

Garche-Kœking, carrière, phase 1, tranche 1

\section{Gilles Mangin}

\section{(2) OpenEdition \\ 1 Journals}

Édition électronique

URL : http://journals.openedition.org/adlfi/8799

ISSN : 2114-0502

Éditeur

Ministère de la culture

Référence électronique

Gilles Mangin, «Thionville», ADLFI. Archéologie de la France - Informations [En ligne], Lorraine, mis en ligne le 01 mars 2001, consulté le 30 avril 2019. URL : http://journals.openedition.org/adlfi/8799

Ce document a été généré automatiquement le 30 avril 2019.

(c) Ministère de la Culture et de la Communication, CNRS 


\section{Thionville}

Garche-Kœking, carrière, phase 1, tranche 1

\section{Gilles Mangin}

Identifiant de l'opération archéologique : F1357200100140

Date de l'opération : 2001 (EX)

1 Une opération de diagnostic a été prescrite sur un terrain de 2 ha situé en plaine alluviale de la Moselle. Les sondages sont descendus à une profondeur de $3 \mathrm{~m}$ à $4,50 \mathrm{~m}$ et ont traversé des dépôts sédimentaires stériles très compacts avec des niveaux d'envasement. Aucun vestige ou indice n'a pu être rencontré lors de cette évaluation archéologique.

\section{INDEX}

Index géographique : Lorraine, Moselle (57), Thionville operation Expertise (EX)

\section{AUTEURS}

\section{GILLES MANGIN}

AFAN 